\title{
Karakteristik Penetrasi dan Laju Pembuangan Material Non Metal pada Proses Drilling dengan Water Jet Machining Sebagai Variasi Stand of Distance
}

\author{
Suhardjono dan Bambang Pramujati \\ Lab. Mesin Perkakas, Jurusan Teknik Mesin -FTI, Institut Teknologi Sepuluh Nopember, Surabaya \\ E-mail: suhardjono@me.its.ac.id
}

\begin{abstract}
ABSTRAK
Untuk penggunaan komersial, WJM membutuhkan pompa tekanan ekstra tinggi dengan daya minimal 300 hp yang akan menaikkan tekanan air hingga 60.000 psi, dimana tekanan sebesar ini akan menghasilkan kecepatan semprotan air hingga 3 Mach (tiga kali kecepatan suara) sehingga dapat memotong material komposit dari serat karbon untuk komponen pesawat tempur anti radar. Namun demikian, penelitian ini hanya mengembangkan sebuah model untuk mempelajari karakteristik proses pemesinan WJM. Model hanya menggunakan pompa dengan daya $3 \mathrm{~kW}$ yang menghasilkan tekanan air sebesar 150 bar (2175 psi). Sebuah batu bata merah dipilih untuk dicoba, karena material ini dapat diukur responnya, yaitu kedalaman penetrasi, diameter lubang dan laju pembuangan material, oleh karena itu batu bata merah ini mempunyai karakteristik yang paling baik untuk mempelajari proses drilling pada WJM. Penelitian ini difokuskan pada bagaimana mempelajari pengaruh parameter SOD (stand of distance). SOD didefinisikan sebagai jarak antara ujung nozel dan permukaan benda kerja. Karakteristik yang diamati adalah pengaruh SOD terhadap kedalaman penetrasi, diameter lubang dan laju pembuangan material pada proses drilling dengan WJM. Hasilnya memperlihatkan bahwa pengaruh SOD mempunyai tendensi kurva parabolik tidak hanya terhadap kedalaman penetrasi dan diameter lubang saja, tetapi juga terhadap laju pembuangan material. Untuk proses drilling dengan diameter nozel $1 \mathrm{~mm}$ dan durasi waktu 10 detik terjadi kenaikan kedalaman penetrasi dari $34 \mathrm{~mm}$ menjadi maksimum $48 \mathrm{~mm}$ atau peningkatan $41 \%$ untuk kenaikan SOD antara $5 \mathrm{~mm}$ dan $15 \mathrm{~mm}$, tatapi untuk SOD antara $15-35 \mathrm{~mm}$ bahkan terjadi penurunan kedalaman penetrasi menjadi $18 \mathrm{~mm}$ atau turun 62,5\% dari harga maksimum. Kenaikan SOD dari $5 \mathrm{~mm}$ menjadi $15 \mathrm{~mm}$ menunjukkan peningkatan laju pembuangan material dari $54,5 \mathrm{~mm}^{3} / \mathrm{s}$ menjadi harga maksimum sebesar $110 \mathrm{~mm}^{3} / \mathrm{s}$ atau praktis dua kali lipat, sebaliknya bertambahnya SOD dari $15 \mathrm{~mm}$ sampai $35 \mathrm{~mm}$ laju pembuangan material bahkan turun lagi menjadi $18 \mathrm{~mm}^{3} / \mathrm{s}$ atau turun 83,63\% dari harga maksimum. Disisi lain, waktu drilling mempunyai hubungan linear terhadap kedalaman penetrasi, tetapi besarnya diameter lubang tidak tergantung pada waktu.
\end{abstract}

Kata kunci: WJM, jarak nozel-benda kerja, WJM drilling, kedalaman penetrasi, laju pembuangan material

\begin{abstract}
For commercial application, Water Jet Machining (WJM) needs at least of 300 hp extra high pressure pump to increase water pressure up to 60.000 psi, which produce water jet velocity as high as 3 Mach (three times sound velocity) in order to cut a carbon fiber composite for aero plane component. However, this research only develops a model to learn the characteristic of machining process of WJM. The model used a $3 \mathrm{~kW}$ pump, which produced water pressure as high as 150 bar (2175 psi). A brick is chosen to be tested, while this material can be measured the response of the depth of penetration, the hole diameter and the metal removal rate, so that the brick have the best characteristic to learn the drilling process of WJM. This research is focused to learn how the effect of stand of distance (SOD) parameter. Stand of distance is defined as the distance between nozzle and work piece surface. The characteristics to be investigated are the effect of SOD on the depth of penetration, on the hole and on material removal rate for drilling process with WJM. The result shows that the effect of SOD has a parabolic tendentious curve not only on the depth of penetration and the hole but also the metal removal rate. For drilling process with 10 second drilling time and $1 \mathrm{~mm}$ nozzle diameter rise the depth of penetration from $34 \mathrm{~mm}$ up to $48 \mathrm{~mm}$ or increased $41 \%$ for SOD between $5 \mathrm{~mm}$ and $15 \mathrm{~mm}$, but for the SOD 15-35 $\mathrm{mm}$ fall the depth of penetration down to $18 \mathrm{~mm}$ or decreased $62.5 \%$. The SOD between $5 \mathrm{~mm}$ and $15 \mathrm{~mm}$ shows that the rate of material removal goes up from $54.5 \mathrm{~mm}^{3} / \mathrm{s}$ to $110 \mathrm{~mm}^{3} / \mathrm{s}$ or practically double, conversely the SOD $15-35$ $\mathrm{mm}$ the material removal rate drops to $18 \mathrm{~mm}^{3} / \mathrm{s}$ or falling down of $83.63 \%$. On the other hand the drilling time has a linear relationship to the depth of penetration.
\end{abstract}

Keywords: Water Jet Machining, stand of distance, drilling, depth of penetration, Material removal rate. 


\section{PENDAHULUAN}

Pemesinan water jet termasuk proses pemotongan dingin, sehingga tidak timbul panas. Dengan demikian tidak terjadi kerusakan akibat panas seperti distorsi termal, HAZ (Heat Affected Zone), tegangan termal (thermal stress) pada permukaan yang dipotong dan lain-lain. Selain daripada itu, water jet machining (WJM) termasuk proses pemotongan yang ramah lingkungan, karena tidak terjadi pelelehan material atau produk sampingan (byproduct) yang berdebu, maka udara disekitarnya tidak tercemar, tidak beracun dan sangat aman dari bahaya kebakaran.

Water jet sebagai pahat potong (cutting tool) mempunyai daya potong yang hampir tidak terbatas, karena water jet dapat memotong berbagai material dari yang lunak hingga yang keras, dari yang ulet hingga yang tangguh dengan tingkat ekonomis yang tinggi. Oleh karena itu WJM berkembang pesat dalam industri arsitektur, ruang angkasa, otomotif, manufaktur, makanan dan buahbuahan, board and paper product, tambang batu bara dan lain sebagainya.

Proses pemotongan water jet diaplikasikan secara komersial pada pertengahan tahun 1970-an. Penggunaan terbesar pada saat itu adalah untuk pemotongan diapers, kertas tissue dan interior otomotif. Water jet dapat bekerja 24 jam sehari, 7 hari per minggu dan 360 hari dalam setahun tanpa terjadi kemacetan (downtime). Dibandingkan dengan proses lain yang terjadi downtime tidak terencana (unplanned downtime) yang merugikan lebih dari US\$20.000,- per jam untuk pabrik diapers dan tissue saja. Pada tahun 1979, Dr. Mohamed Hashish bekerja pada flow research, mulai meneliti metode untuk meningkatkan daya potong dari water jet sehingga dapat memotong metal dan material keras lainnya. Metode yang dikembangkan adalah dengan menambahkan partikel abrasive dalam aliran water jet, sehingga metodenya disebut abrasive water jet machining (AWJM). Hasilnya pada 1980 untuk pertama kalinya abrasive water jet memotong baja, kaca dan beton. Pada 1983 secara komersial abrasive water jet dijual untuk pemotongan kaca pada industri otomotif.

Himmelreich [1] dalam penelitiannya menemukan bahwa semakin tinggi tekanan pompa, profil kecepatan water jet menjadi semakin uniform. Dia juga menemukan bahwa semakin tinggi tekanan, maka ketergantungan kecepatan rata-rata pada diameter fokusnya semakin berkurang. Selain tekanan pompa, ternyata nozzle pun sangat berpengaruh pada karakteristik water jet. Desain nozzle yang paling optimal dianalisis dalam desertasi Nienhaus [2], bahwa sudut kerucut (included angle) $13^{\circ}$ dan bagian lubang nozzle yang lurus antara 2-5 kali diameternya akan memberi- kan panjang jet efektif yang maksimal. Desain ini juga dibuktikan dengan eksperimental oleh Mazurkiewicz [3], bahwa panjang pancaran efektif (effective jet length) yang paling baik adalah sudut kerucut antara $12^{\circ}$ dan $13^{\circ}$. Panjang pancaran efektif juga tergantung pada bagian diameter pipa nozzle yang lurus (throath length) dan yang terbaik adalah 4 kali diameternya.

Dalam aplikasi proses pemesinan, Orbanic dan Junkar [4] melakukan studi ekperimental penggunaan partikel abrasive pada water jet untuk proses drilling lubang kecil dan dalam (small and deep hole). Percobaan proses drilling dilakukan pada beberapa material yang berbeda, sedangkan kedalaman dan diameter lubang diamati untuk waktu drilling yang berbeda. Hasilnya kedalaman dan diameter lubang meningkat dengan fungsi eksponensial (power function).

Hasil percobaan awal yang dilakukan oleh Suhardjono et.al. [5] memperlihatkan bahwa dengan menaikkan SOD (Stand of Distance) hingga jarak SOD optimum akan terjadi kenaikan gaya luaran semprotan air (water jet) yang keluar nozzle, namun kenaikan SOD yang melampaui SOD optimum tersebut bahkan terjadi penurunan gaya luarannya yang sangat signifikan.

\section{METODE PENELITIAN}

Pembuatan lubang atau proses drilling (pembuatan lubang) dengan WJM dilakukan dengan menghentikan gerak makan (feed) arah horizontal dan ditahan pada suatu titik tertentu dalam waktu tertentu pula hingga kedalaman lubang yang dikehendaki dapat dicapai. Prinsip proses drilling dengan WJM dapat digambarkan seperti ilustrasi gambar 1 berikut ini.

Karena dalamnya lubang tidak terlihat, maka waktu drilling $t_{d}$ yang diukur. Selanjutnya proses dihentikan dan kedalaman penetrasi lubang diukur. Misalnya diameter lubang yang terjadi adalah $d$, maka volume material yang terbuang adalah:

$$
V=\frac{\pi}{4} d^{2} \cdot h\left(\mathrm{~mm}^{3}\right)
$$

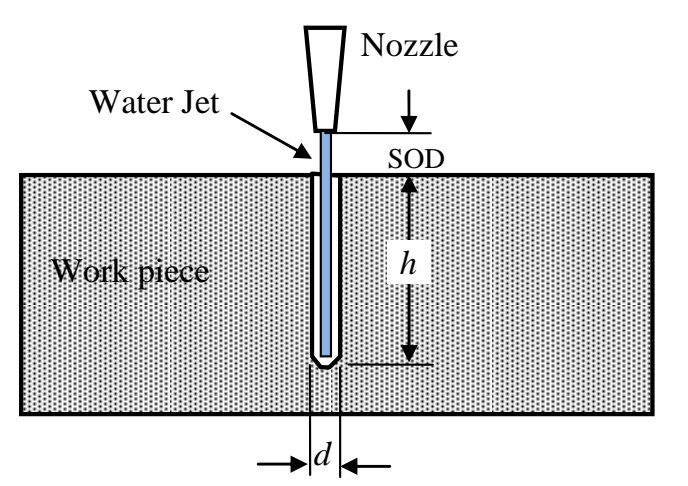

Gambar 1. Ilustrasi Proses Drilling dengan WJM 


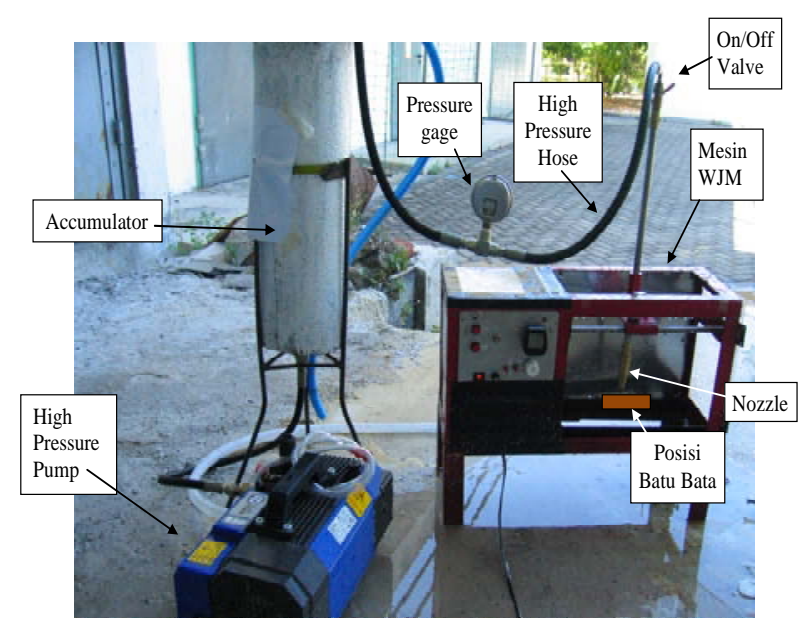

Gambar 2. Peralatan Penelitian

Sehingga laju pembuangan material atau material removal rate (MRR) dihitung sebagai berikut:

$M R R=\frac{V}{t_{d}}\left(\mathrm{~mm}^{3} /\right.$ detik $)$

Rangkaian peralatan percobaan water jet machining ditunjukkan sesuai pada Gambar 2. Prinsip kerja dari instalasi Gambar 2 dapat dijelaskan sebagai berikut:

Air dalam volume yang besar ditampung pada tandon agar dapat mensuplai kebutuhan dengan debit 480 liter/jam dari pompa tekanan tinggi yang menaikkan tekanan hingga 150 bar (15 $\mathrm{MPa}$ ) atau sekitar 2175 psi yang membutuhkan daya listrik 3 $\mathrm{kW}$. Agar air yang masuk dalam pompa tidak tercampur kotoran dan partikel abrasive lainnya yang dapat memperpendek umur pompa, maka air tersebut perlu disaring dengan filter. Untuk mencegah aliran balik dipasang check valve sebelum dan sesudah pompa. Air dengan tekanan tinggi kemudian ditampung di dalam akumulator agar tekanan dapat lebih stabil saat digunakan proses pemotongan.

Exhaust valve (terpasang setelah akumulator) disini berfungsi untuk membuang udara yang terperangkap saat awal proses pemompaan air ke akumulator, dimana udara yang terperangkap dapat menurunkan tekanan air dalam akumulator. Untuk mencegah terjadinya ledakan akibat kelebihan tekanan, maka dipasang katup pengaman (safety valve) yang secara otomatis terbuka, jika tekanan melebihi tekanan yang diijinkan. Besarnya tekanan air dapat dibaca pada pressure gauge yang dipasang sebelum katup buka tutup (On/Off valve). Proses pemotongan dilakukan dengan cara membuka katup On/Off sehingga air dengan tekanan tinggi akan keluar melalui nozzle dengan kecepatan yang sangat tinggi, disinilah terjadi perubahan energi dari tekanan menjadi energi kinetik. Akhirnya energi kinetik ini yang akan mengerosi benda kerja, sehingga terjadi proses drilling.

\section{HASIL DAN PEMBAHASAN}

Proses drilling dilakukan dengan mengatur ketinggian Stand Of Distance (SOD) tertentu dan katup dibuka dengan waktu selama 2 detik, kemudian dipindah ke posisi yang lain untuk drilling lubang yang lain dan ditandai untuk SOD yang ditentukan tadi. Untuk setiap SOD dilakukan drilling minimum tiga lubang untuk replikasi. Variasi SOD diatur dari $5 \mathrm{~mm}$ hingga $35 \mathrm{~mm}$ dengan selang $5 \mathrm{~mm}$. Sedangkan waktu drilling untuk masing-masing SOD dinaikkan dari 2 detik hingga 10 detik dengan tahapan 2 detik.

Gambar 3 menunjukkan bahwa grafik pengaruh SOD terhadap kedalaman penetrasi secara keseluruhan dengan diameter nozzle $1 \mathrm{~mm}$ dan tekanan pompa konstan sebesar 150 bar. Dari grafik dapat dilihat pada SOD $5 \mathrm{~mm}$ dengan waktu drilling mulai dari 2 detik sampai 10 detik terjadi peningkatan kedalaman penetrasi yang signifikan. Begitu juga antara SOD $10 \mathrm{~mm}$ dan SOD $15 \mathrm{~mm}$ masih terjadi tren kenaikan kedalaman penetrasi. Pada saat SOD diatas $15 \mathrm{~mm}$ dengan waktu drilling mulai 2 detik sampai 10 detik terjadi sebaliknya, yaitu penurunan kedalaman penetrasi yang terus terjadi hingga SOD $35 \mathrm{~mm}$ apabila dibandingkan dengan kedalaman penetrasi yang terjadi antara SOD $5 \mathrm{~mm}$ sampai SOD $15 \mathrm{~mm}$.

Pancaran air yang keluar melalui lubang nozzle menghasilkan energi kinetik dengan kecepatan tinggi. Ketika pancaran air yang keluar dari nozzle berbenturan dengan permukaan bata merah dengan sudut 90 derajat (tegak lurus), pancaran air tersebut akan menyebar secara radial diatas pusat benturan. Ketika pancaran air dengan kecepatan tinggi tersebut diarahkan pada suatu titik pada permukaan benda kerja dan tepat mengenai permukaan bata merah, maka energi kinetik dengan kecepatan tinggi tersebut akan menekan permukaan material. Karena terus ditekan lama kelamaan permukaan bata merah akan terkikis sedikit demi sedikit (mengalami erosi), dan pada akhirnya akan timbul lubang. Banyaknya material yang terkikis oleh pancaran air tersebut disebut MRR (Material Removal Rate) atau laju pembuangan material.

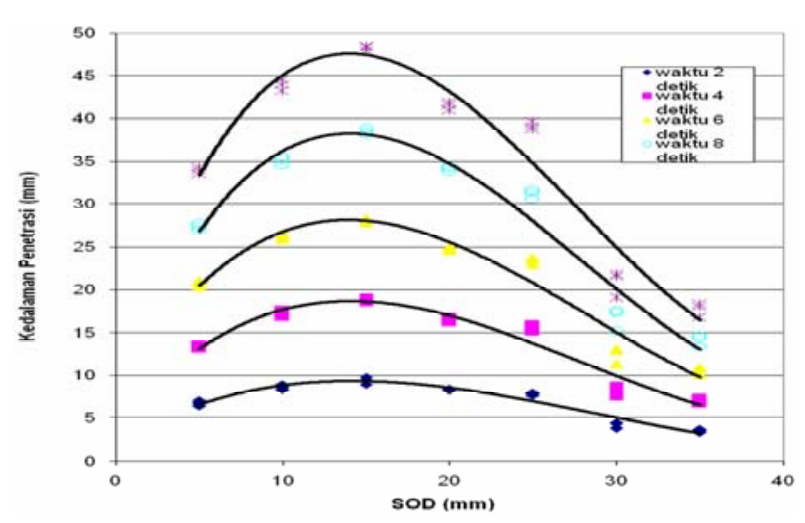

Gambar 3. Hubungan Antara SOD dan Kedalaman Penetrasi 
Jadi secara garis besar water jet machining adalah proses pemotongan yang berlangsung karena memanfaatkan pancaran air dengan kecepatan yang tinggi, dan mempunyai energi kinetik yang sangat tinggi pula. Dengan tekanan yang sangat tinggi permukaan benda kerja sedikit demi sedikit akan terkikis atau tererosi. Erosi terjadi dikarenakan tekanan air melebihi kekuatan ikatan partikelpartikel dari material benda kerja tersebut.

Pada SOD $15 \mathrm{~mm}$ pancaran air memiliki efektifitas paling tinggi dimana pancaran air dengan kecepatan tinggi yang disertai dengan energi kinetik yang membentur permukaan benda kerja menghasilkan energi yang sangat besar sehingga menyebabkan kedalaman penetrasi yang sangat dalam. Dengan waktu pengambilan data yang semakin bertambah maka kedalaman penetrasi pun akan bertambah seiring dengan pertambahan waktu. Akan tetapi hal tersebut tidak terjadi pada SOD yang lebih kecil (SOD $5 \mathrm{~mm}$ ) karena saat air menumbuk material, pancaran air pada titik tumbukan belum terbentuk secara sempurna dikarenakan energi yang dihasilkan akibat tumbukan sudah ditumbuk lagi oleh pancaran air berikutnya karena jarak antara nozzle dan benda kerja yang cukup dekat.

Pada SOD di atas $15 \mathrm{~mm}$ sampai SOD $35 \mathrm{~mm}$ besar energi yang menumbuk benda uji akan semakin turun terus dikarenakan semakin jauh jarak antara nozzle dan benda kerja maka pancaran air akan semakin melemah sebab air yang terpancar akan semakin besar mengalami gesekan dengan udara sekitar, hal tersebut menyebabkan pancaran air akan semakin lemah. Hal inilah yang menyebabkan kedalaman penetrasi terus turun seiring dengan bertambahnya jarak pada SOD 15 mm sampai SOD 35. Pada Gambar 3 penurunan nilai kedalaman penetrasi terjadi mulai dari SOD 15 mm sampai SOD $35 \mathrm{~mm}$.

\section{Pengaruh SOD pada Diameter Lubang}

Pengaruh SOD terhadap diameter lubang yang terjadi pada proses drilling batu bata ditunjukkan pada Gambar 4.

Pada Gambar 4 memperlihatkan grafik pengaruh SOD terhadap diameter lubang secara keseluruhan dengan diameter nozzle $1 \mathrm{~mm}$ dan tekanan pompa konstan sebesar 150 bar. Dari grafik dapat dilihat pada SOD $5 \mathrm{~mm}$ hingga $15 \mathrm{~mm}$ dengan waktu drilling mulai dari 2 detik sampai 10 detik terjadi peningkatan diameter lubang yang cukup signifikan. Sedangkan SOD lebih besar dari $15 \mathrm{~mm}$ bahkan terjadi penurunan diameter lubang yang terus terjadi hingga SOD $35 \mathrm{~mm}$.

Pada SOD $15 \mathrm{~mm}$ pancaran air memiliki efektifitas paling tinggi dimana pancaran air dengan kecepatan tinggi yang disertai dengan energi kinetik

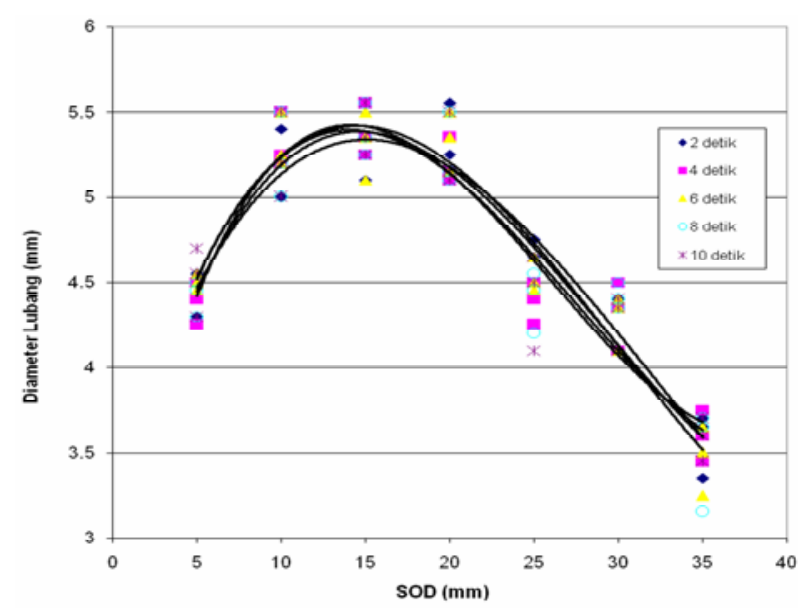

Gambar 4. Hubungan Antara SOD dan Diameter Lubang

yang membentur permukaan benda kerja menghasilkan energi yang sangat besar sehingga menyebabkan diameter lubang yang besar. Akan tetapi hal tersebut tidak terjadi pada SOD yang lebih kecil (SOD $5 \mathrm{~mm}$ ) karena saat air menumbuk material, pancaran air pada titik tumbukan belum terbentuk secara sempurna dikarenakan energi yang dihasilkan akibat tumbukan sudah ditumbuk lagi oleh pancaran air berikutnya karena jarak antara nozzle dan benda kerja yang cukup dekat.

Untuk SOD diatas $15 \mathrm{~mm}$ sampai SOD $35 \mathrm{~mm}$ besar energi yang menumbuk benda kerja akan terus menurun, hal ini dikarenakan semakin jauh jarak antara nozzle dan benda kerja maka pancaran air akan semakin melemah sebab air yang terpancar akan semakin besar terkena gesekan dengan udara sekitar dan kehilangan kecepatan, hal tersebut menyebabkan pancaran air akan semakin lemah. Atau dengan kata lain bahwa semakin besar SOD terjadi kehilangan energi kinetiknya.

Hal inilah yang menyebabkan diameter lubang terus mengecil seiring dengan bertambahnya jarak pada SOD diatas $15 \mathrm{~mm}$ sampai SOD $35 \mathrm{~mm}$. Pada Gambar 4 juga terlihat dengan jelas bahwa besarnya diameter lubang tidak tergantung pada waktu drilling nya, hal ini disebabkan oleh pancaran air arah radial yang mengerosi dinding lubang yang tidak dipengaruhi waktu.

\section{Pengaruh SOD pada MRR}

Pada Gambar 5 menerangkan grafik pengaruh Stand of Distance (SOD) terhadap laju pembuangan geram (MRR) $\left(\mathrm{mm}^{3} / \mathrm{s}\right)$ secara keseluruhan dengan diameter nozzle $1 \mathrm{~mm}$, lama waktu drilling mulai 2 detik, 4 detik, 6 detik, 8 detik, dan 10 detik dan tekanan pompa konstan yaitu 150 bar. Pada saat SOD diatas $15 \mathrm{~mm}$ mulai terjadi penurunan nilai MRR yang terus terjadi hingga SOD $35 \mathrm{~mm}$ bila dibandingkan dengan nilai MRR yang terjadi pada SOD $5 \mathrm{~mm}$ sampai SOD $15 \mathrm{~mm}$. 


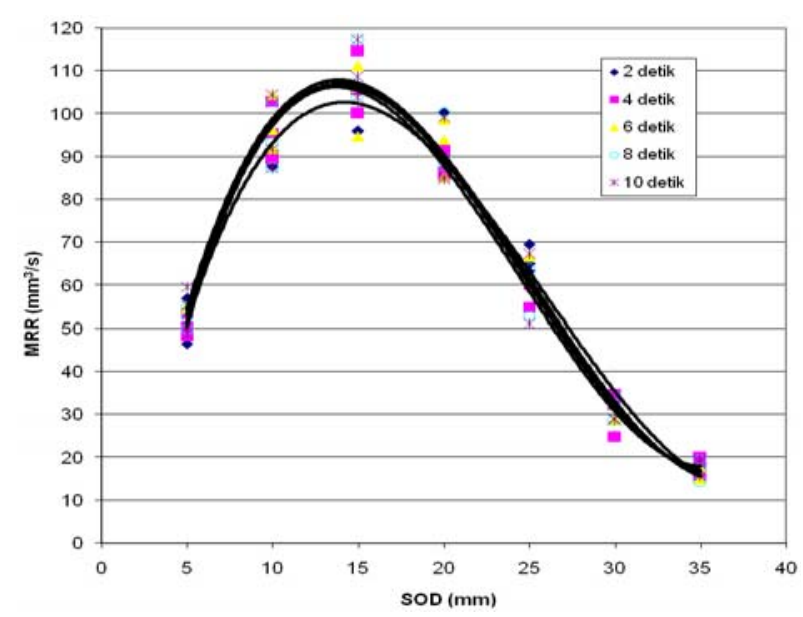

Gambar 5. Hubungan Antara SOD dan MRR

Hal ini diakibatkan pada jarak SOD $15 \mathrm{~mm}$ pancaran air memiliki efektifitas tinggi dimana pancaran air mampu menghasilkan energi yang maksimum untuk dapat mengerosi benda kerja. Akan tetapi hal tersebut tidak terjadi pada SOD yang lebih kecil (SOD $5 \mathrm{~mm}$ ), rendahnya MRR pada SOD kecil dikarenakan oleh semakin besarnya tahanan atau resistansi pancaran air saat keluar dari nozzle.

Selanjutnya besar energi yang dihasilkan oleh pancaran air pada SOD diatas $15 \mathrm{~mm}$ sampai SOD $35 \mathrm{~mm}$ akan semakin turun terus dikarenakan semakin jauh jarak antara nozzle dan benda kerja maka pancaran air akan semakin melemah sebab air yang terpancar akan semakin besar mengalami gesekan dengan udara sekitar, sehingga menyebabkan material yang terkikis tidak begitu banyak akibat banyaknya energi kinetik yang hilang tersebut. Hal inilah yang menyebabkan nilai MRR yang dihasilkan terus menurun seiring dengan pertambahan SOD antara $15 \mathrm{~mm}$ sampai $35 \mathrm{~mm}$. Sekali lagi tren dari pola grafik pengaruh SOD terhadap hasil proses drilling untuk material batu bata apakah yang diamati kedalaman penetrasi lubang, diameter lubang ataupun MRR memperlihatkan bahwa terdapat kemiripan dengan grafik gaya luaran sebagai fungsi SOD pada penelitian yang terdahulu oleh Suhardjono et.al.[5].

\section{Pengaruh Waktu pada Kedalaman Penetrasi Lubang}

Hasil grafik pengaruh waktu drilling terhadap kedalaman penetrasi lubang tersebut ditunjukkan pada Gambar 6. Dari Gambar 6 tersebut terlihat jelas bahwa pengaruh waktu terhadap kedalaman penetrasi mempunyai hubungan linear. Jadi semakin lama waktu drilling, maka semakin dalam pula penetrasi lubang yang terjadi. Hal ini tentu saja disebabkan oleh semakin besar tersedianya waktu proses erosi dengan kecepatan erosi yang tertentu.

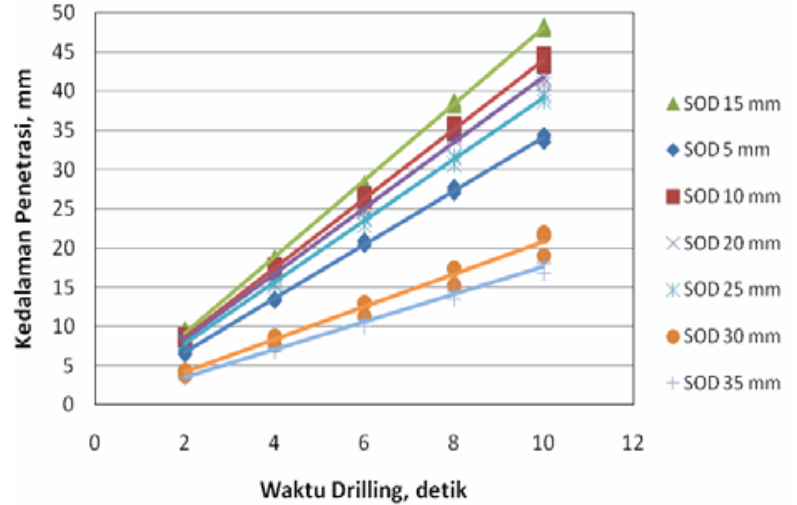

Gambar 6. Hubungan Antara Waktu Drilling dan Kedalaman Penetrasi Lubang

\section{KESIMPULAN}

Jarak antara nozzle dan benda kerja atau SOD (stand of distance) mempunyai pengaruh yang sangat besar terhadap kedalaman penetrasi lubang, diameter lubang dan laju pembuangan material. Untuk Proses drilling pada batu bata menghasilkan data bahwa kedalaman penetrasi lubang, diameter lubang dan laju pembuangan material (MRR) sebagai fungsi SOD memberikan tren (kecenderungan) pola grafik parabolik yang mempunyai titik optimum tertentu. Dengan demikian kenaikan SOD hingga SOD optimum, semakin besar SOD semakin besar pula kedalaman penetrasi, diameter lubang dan MRR. Namun di atas SOD optimum mulai terjadi penurunan yang sangat signifikan. Waktu proses drilling sangat berpengaruh terhadap kedalaman penetrasi saja dan mempunyai hubungan linear. Jadi semakin lama waktu drilling semakin dalam penetrasi lubang yang terjadi. Sedangkan diameter lubang dan laju pembuangan material praktis tidak dipengaruhi oleh waktu proses drilling.

\section{Ucapan Terima Kasih}

Ucapan terima kasih ini disampaikan kepada:

1. Ditjen DIKTI melalui program DP2M dalam memberikan dana Hibah Penelitian Fundamental untuk tahun pertama 2009.

2. Kepada Mahasiswa S1 jurusan Teknik Mesin FTI-ITS, yaitu Satya Lagawan, Zulfikar Rusdi Firmansyah dan Indra Kusuma Wardana.

3. Kepada anggota tim peneliti dan Teknisi Laboratorium

4. Semua pihak baik yang langsung maupun tidak langsung berpartisipasi aktif membantu hingga dapat diselesaikannya penelitian Fundamental tahun pertama ini.

\section{DAFTAR PUSTAKA}

1. Himmelreich, U., Fluiddynamische Modellunterschungen an Wasserabrasivstrahlen. VDI Fortschritt-Berichte, Reihe 7, Nr 219, 1992. 
2. Nienhaus, K., Ein Beitrag zur Gesteinszerstoerung Durch Stationaere und Instationaere Hoechstdruckwasserstrahlen, Ph.D. thesis, RWTH Aachen, Aachen, 1984.

3. Mazurkiewicz, M., Fincuan, L., Ferguson, R. 1987, Investigation of Abrasive Cutting Head Internal Parameters. In: Woods, P.A. (ed), Proceedings $9^{\text {th }}$ International Symposium Jet Cutting Technology, BHRA Fluid Engineering, Cranfield, pp 75-84, 1987.
4. Orbanic, H. And Junkar, M., An experimental study of drilling small and deep blind holes with an abrasive water jet, Journal of Engineering Manufacture, London, May 2004 Vol. 218, Iss. 5 p. 503, 2004.

5. Suhardjono, Efendi, M.C. and Firmansyah, Z.R., Studi Eksperimental Pengaruh Variasi Stand of Distance terhadap Gaya potong pada Proses Water Jet Machining, Prosiding Seminar Nasional Tahunan Teknik Mesin (SNTTM) VIII, pp. 207215, Universitas Diponegoro, Semarang 11-12 Agustus 2009. 